\title{
Perceptions of the elderly on aging and violence in intrafamily relationships
}

\section{Abstract}

Objective: To identify the different perceptions of the aging process and violence in intrafamilial relations of elderly participants of a social and coexistence group. Method: An exploratory and descriptive qualitative study was performed through the application of a sociodemographic questionnaire and a semi-structured interview, with seven elderly people participating in the Coexistence and Strengthening of Bonds social group. The results of the discourses were assessed through thematic content analysis. Results: The extraction into thematic units allowed the elaboration of two intertwined categories: self-perception of the process of intrafamily aging and violence in the eyes of the elderly. Conclusion: The elderly reported that the family is responsible for providing care, appreciation and understanding, and that the aging process brings new possibilities for coexistence, but it is also accompanied by weaknesses and limitations. They also indicated subtle practices of psychological, financial, and abandonment violence, making them impotent, ashamed, and fearful to adopt effective initiatives to restore cordial, ethical, and harmonious family relationships.

\footnotetext{
Universidade de Passo Fundo (UPF), Programa de Pós-graduação em Envelhecimento Humano. Passo Fundo, RS, Brasil

2 Universidade de Passo Fundo (UPF), Programa de Graduação em Serviço Social.. Passo Fundo, RS, Brasil.
}

No funding was received in relation to the present study.

The authors declare there are no conflicts of interest in relation to the present study.

Correspondence

Nadir Antonio Pichler

Eliane Lucia Colussi' $\mathbb{D}$ Amanda Kuyawa $^{2}$ (D) Ana Carolina Bertoletti De Marchi' $\mathbb{I D}^{2}$ Nadir Antonio Pichler' (ID)

Keywords: Aging. Violence. Family. Health of the Elderly. 


\section{INTRODUCTION}

The growing process of population aging in various parts of the world is a demographic phenomenon that has repercussions for various dimensions of the social and individual sphere. Aging is a dynamic process, permeated by biological, physical, psychological, environmental, cultural and social modifications ${ }^{1}$. In addition, "these multiple factors associated with the aging process interact and regulate both typical and atypical functioning of the aging individual"

The concept of aging is dynamic. For Mucida ${ }^{3}$, "social discourse minimizes its complexity from denominations associated with the years lived by the person, social security contributions, years worked, the third age, among others". The author refers to the different ways of aging and the various perceptions of the process experienced by the individual, such as changes in image, in the body and in social ties that impact considerably on feelings.

The aging process of the population presents changes in the configuration of the elderly and their relationship with other people, both in the family and social environments. In this context, factors such as identity crisis, role changes and the impact of retirement stand out, in addition to the various losses experienced and a reduced social life. Health problems, coping in the sphere of public policy, the training of professionals to care for older people, among other aspects, are becoming more frequent ${ }^{2}$.

In this context, an important debate to be addressed concerns the various forms of violence against the elderly, the most common of which are physical; psychological; sexual; financial and economic; neglect and abandonment ${ }^{4,5}$. Among those mentioned, intrafamily violence is gradually getting worse, with repercussions for people's lives ${ }^{1}$. The elderly can become victims of violence when they are dependent on their families in a range of aspects. Up to four generations are known to reside in the same household. Thus, facing the different demands associated with the presence of elderly people in the same family is a challenge, as there is practically no succession planning and little knowledge about the aging process in rural areas ${ }^{6}$.

Regardless of what is advocated by legislation ${ }^{7}$, it is within the family that affective bonds are established, and which is one of the main sources of protection and care for the elderly. The quality of the relationship between the elderly and their families depends on several factors, as Lafin ${ }^{8}$ points out: gender, housing, personal history and physical and mental health. It is understood that the more serious the problems, such as rejection and violence, the more difficult are the relationships and the ability to deal with weaknesses on the part of the elderly and their families?.

Violence against the elderly presents itself as a social, economic, cultural, health and family problem. For Rocha et al., ${ }^{10}$ the neglect involved in the various forms of violence against the elderly is invisible and silent, in the physical, mental, financial and self-neglect spheres, treating them as if they were "disposable". Therefore, the first reactions of elderly victims of domestic violence are fear, shame and guilt, as they realize the failure of family relationships. Saidel and Campos ${ }^{11}$ state that the victims seek to omit and even accept practices of violence as natural, "as if the elderly were to blame for the situation in which they find themselves".

For Minayo ${ }^{12}$, violence in Brazil has historically been structured into nuclei: structural (inequality, poverty, deprivation, discrimination), institutional (inefficient public policies and rational/legal domination) and interpersonal (forms of communication and everyday relations of indifference). Consequently, many elderly persons are victims of these forms of violence, especially interpersonal violence, which erodes and produces suffering in the process of living and aging in intrafamily living. According to Beauvoir ${ }^{13}$, there is silent, subtle, hidden and stereotyped violence towards old age, considered normal by contemporary society.

The present study aimed to identify the different perceptions of the aging process and violence in the intrafamily relationships of elderly participants of an activity and social group. 


\section{METHOD}

An exploratory and descriptive, qualitative research study was conducted in August 2016, in the interior of the state of Rio Grande do Sul, Brazil. According to data from the Brazilian Institute of Geography and Statistics (IBGE), this municipal district had a population of 2,196 people. Of this total, 364 were 60 years of age or older, making up $16.5 \%$ of the population ${ }^{14}$.

The study was conducted in a Coexistence and Strengthening of Bonds social group, linked to the Social Assistance Reference Center (or CRAS). This group consisted of 80 participants, who met once a month for study, debate and leisure. To achieve the objective of the study, seven people were selected, who had signs of recurrent intrafamilial violence and who had already been visited and monitored by the social services, with improvements in the family relationship.

A sociodemographic questionnaire (age, gender, income, marital status, home, retired and if lives with family) and semi-structured interview were used for data collection. The guiding questions for the interviews were: How did you imagine your life at this stage? What is violence for you? How would you describe your relationship with your family? How would you describe your day to day life with your family?

The inclusion criteria were: having previous knowledge of the work and care performed by the CRAS technical team and having suffered some kind of violence by family members in the last two years.

The interviews were conducted in a location defined by the participants, who mostly opted for their homes, had an average duration of 70 minutes, and were audio recorded and then transcribed. The information was synthesized by Bardin's content analysis $^{15}$, by means of a skim reading, rereading, identification of repetitive positions, constants and the like; and then corroborated with the literature on the subject, mainly the Manual to Confront Violence Against the Elderly ${ }^{12}$.

Finally, the discourses were grouped into categories by units of meeting. The elderly were named with the letter P for participant, followed by sequential numbering: P1 to P7.

The study was approved by the Ethics Research Committee of the Universidade de Passo Fundo, Rio Grande do Sul, under opinion no 1.661.297. All participants signed a Free and Informed Consent Form (FICF).

\section{RESULTS AND DISCUSSION}

The ages of the participants ranged from 64 to 77 years, six were married with children, retired and resided in their own home or with family. Four lived in the rural area and three in the urban area of the municipal district. The average monthly income of respondents was one minimum wage. Based on the results of the interviews and following content analysis, two categories emerged: Self-perception of the intrafamily aging process and Violence in the eyes of the elderly.

\section{Self-perception of the intrafamily aging process}

The aging process occurs in various ways, with each individual perceiving their aging in a particular and individual way. According to Mucida ${ }^{3}$, there is no old age per se, but different ways "in which it presents itself." For elderly people living in a small town in the interior of Rio Grande do Sul, Brazil, of rural origin and characteristics, such perceptions are even more distinct. Culture, identity, education, family relationships and religiosity affect the way of being and seeing in the world.

The participants confirmed these different ways of seeing the world. $\mathrm{P} 1$ expressed himself in a positive manner, reporting that he had always seen himself as a doting grandfather. He revealed that he had not been as affectionate with his own children as he has with his grandchildren. This statement may be an indication that the elderly seek to compensate for the probable lack of love felt by their own children, as "it is really nice to be a grandfather and have them [grandchildren] around" (P1).

The role of the family is fundamental at any stage of life and becomes relevant during two distinct 
periods: in childhood and adolescence and in old age. When analyzing the family institution, it appears to present constant structural transformations, such as the reorganization of the responsibilities of primary providers based on care needs, in the case of the elderly $y^{4-6,13,16}$.

The aging process and advanced age emerged in the discourse of the participants, with P2, P3, P4 and P5 demonstrating that time, age, autonomy and independence are intrinsically connected to the historical and cultural context, revealing contradictory feelings, such as fear of loneliness, insecurity, dependence and the projection of aging with more dignity and happiness. Regarding this issue, one of the participants said:

"I couldn't wait to reach old age, so I would have fun, I would go out, I would be happier. [But] I'm always alone. I have my husband, but he works a lot, away from home". (P4)

The study developed by Menezes et al. ${ }^{17}$, with 20 participants over 60 years of age, found that "the elderly are increasingly active and participative in today's society", making them, despite the difficulties of life, happier "at this stage of life." For Minayo", character and lifestyle help the elderly to overcome existential contingencies and have self-esteem, confidence and self-care. This helps promote dignity in old age by sharing the belief in building a better society for all with adults and young people.

The participants also revealed that the aging process was rewarding, with participation in social groups. This space of social insertion and sociability was an alternative to escaping loneliness, the absence of children (P5, P7) and overcoming obstacles with partners, as attested in two statements:

"I always imagined that I was going to take part in the seniors group, and I couldn't wait to turn 55 so I could go, talk, have fun". (P6)

"I have no sons or grandsons living with me. My husband drank a lot. I was suffering, I had very serious depression, for no reason. It was because I was alone”. (P4)
Most of the older people who participate in social groups are women. Even before the age of 60, many are determined and intent on joining a group because they are welcomed, listened to and gain a new space to develop self-care. These reciprocal exchanges contributed to the intertwining of thoughts and new life projects, accompanied by listening, respect, dignity, new learning and the synthesizing of new meanings for their existence. Thus, they break with the patterns of domination to which they were probably submitted in life, an attitude capable of generating autonomy, independence and strengthening'. The group also represents a motivational space for facing daily difficulties, exchanging experiences and seeking understanding of oneself and others ${ }^{1,2,5}$.

It is important to present the results of the study by the anthropologist Leo Simmons, cited by Minayo $^{12}$, regarding the life expectancy of elderly people from 71 indigenous societies, summarized in the following statements: Live as long as possible, concluding life with dignity and without suffering, in need of care due to the progressive decrease of your capabilities, as well as being able to participate in community decisions and having access to "social achievements and prerogatives such as properties, authority and respect".

\section{Violence in the eyes of the elderly}

The participants reported their perceptions and understandings of violence, according to their experiences. Among the forms of violence that emerged explicitly and implicitly are psychological and financial.

P1 and P2 reported that they had two daughters and that the family experience generated suffering, causing psychological violence. Even trying to minimize such hostile relationships, they revealed helplessness due to enmity among their daughters, absence, separation, and little money from one of them:

"One thing has upset me already, but I never took it seriously. My daughters never answered me, they always respected me a lot. [...]. I miss her. My 
daughter was widowed and had no money because her late husband spent it on parties, drink, and a car. And now she has nothing. She has only the house and her husband never paid INSS. She has no pension and she doesn't get along with her sister. [...]. We can't always call because everything is so expensive" (P1).

"We live in the basement of one of the daughters and I would be so happy if they were both close, living harmoniously, [but I'm] living and fighting to have my daughters here" (P2).

Violence against the elderly presents itself as a social, economic, cultural, health and family problem. For Minayo ${ }^{12}$ there are three major prejudices that generate violence against the elderly: disease, decay and the understanding of their condition as a problem. "In fact these three negative myths are intertwined and potentiate violence." For Beauvoir ${ }^{13}$, considering the elderly person as inactive and passive, especially deprived of liberty, is a form of violence.

There are several forms of aggression against the elderly, the most frequent of which are physical, financial, psychological, sexual, neglect and abandonment, especially psychological aggression, as it causes insecurity and fear for the elderly ${ }^{13,15,16}$. Saidel and Campos ${ }^{11}$ describe long-term psychic suffering "as like a chronic condition," followed by exhaustion, tiredness, and intolerance. An existence marked by such conflicts on a daily basis involves the living and aging of the elderly person as a whole, as a body, community and environment, and in the biological, social, psychic and spiritual dimensions, with all their multidimensionalities ${ }^{1,2,9,12}$. Thus, P4 conceives violence in an extreme manner. He claims he was never a victim, but mentions and positions himself in relation to money as follows:

"I don't like violence, nor even talking about it, I can't sleep when I think about it. Violence for me is killing, stealing, beating. She says her husband respects her, and even when he got drunk he never said anything. [But] in terms of my money, sometimes they ask me for it (the children), and I give it to them, but because I want to, they never made me give them money" (P4).
From the same perspective, participant P5 stated that she had never suffered violence. She had six children, one of whom was deceased. She says she has lived with one son and her daughter-in-law for five years (then she paused). However, she revealed that in the early days, when the couple had a small baby, the daughter-in-law would not let her pick her up. Only when her son came home from work did he "take the baby and put her on my lap; she wouldn't give it to me but now she's got better, but when she makes mate tea she won't offer me one if her husband isn't around" (P5).

This same interviewee also said that her daughterin-law did not allow her to prepare meals and "she would not let me do anything". But now, recently, she lets her cook and do her own laundry, apart from the "bedclothes, that's right, they're the ones who wash me". This change in her daughter-in-law's behavior occurred after the "CRAS social worker held a meeting with them". The elderly woman believed that the improvement was due to the "social worker talking to them and telling them how it is". The social worker helped establish an understanding of what seemed to be exploitative. According to the elderly women, the money she offered, she gave "to them with pleasure [..]. I gave $\mathrm{R} \$ 500$ to buy food, of the rest I spend a lot on doctors and medicine. She (daughter-in-law) never judged me for not doing things, she gets everything ready in the sink and I cook. But she has changed a lot" (P5).

Tavares et al. ${ }^{18}$ describes how many of these relationships are not established in a peaceful and harmonious manner, "such as in the case of retired elderly persons who are exploited and subjected to violence or are abandoned by their families." In this sense, among the main results in the study, it was found that: a) $80 \%$ of the elderly were responsible for at least half of their family's income; b) family dependence is related to problems such as unemployment, low pay, unplanned pregnancy, divorce and other events; c) due to their pensions, they assume new roles in the family; d) contributing to the material maintenance of their families is considered an obligation for the elderly, as a show of gratitude for the care received. 
Based on the reports of the participants, there is a perception of the role reversal of the elderly in relation to their children. Instead of being cared for, it is the elderly who continue to care for their children and grandchildren. Therefore, the bonds of affection, love and care fall short of the expectations of the elderly parents. For Mucida ${ }^{3}$, when the health of the elderly person requires care, there is an inversion of the caregiver and the care recipient. One of the causes of this lies in the absence of cordial relationships and indifference between parents and children during life and the "tendency for children to be absent when the elderly depend on them". In this sense, according to Minayo ${ }^{12}$, in intrafamily living there are many prejudices, manifested in expressions such as: "they are a burden"; "they are unproductive"; "they are sick"; "they spend a lot"; "the resources for their retirement would be better spent if they went to young people".

For P6, violence is an evil. He initially stated that he did not give his son money but paid his bills. He describes how "then I had to sell a small piece of land to pay one of my son's bills at the bank, [...] if he didn't pay, he could have lost everything". The old man paid the debt and the son did not return the money. But "today, he doesn't ask for money, I give him a little money to pay for the water and the electricity, since he lives with me. At home I help do the laundry, make lunch and take care my grandson".

For Santos-Orlandi et al. ${ }^{16}$, in Brazil and other countries, it has become common for the elderly to take care of their grandchildren, due to their children's financial difficulties. However, this seemingly charitable practice is accompanied by depressive signs; isolation; physical and mental suffering; cognitive changes; arterial hypertension; weight loss; physical inactivity; fatigue; low grip strength; slow gait, "negatively impacting the caregiver's quality of life". Moreover, there is a fear among children that grandparents will interfere too much in the education of their grandchildren. However, this financial dependence is increasingly frequent and recurrent. In the same study, "most of the older caregivers were female" and belonged to the 60 to 69 years old age group".
Another aspect of violence emerged in the discourse of P7. She revealed that her husband is an alcoholic and sought help from social services. She tried to persuade her husband to seek support from an alcoholic support group, but he didn't accept it, because "I don't want him to die. He is a family man, we did everything, [...] he had lost his head. But in my prayers, [...] I got everything I wanted, and he became a family man again overnight." With professional help, her husband stopped drinking and she says that if "he had gone to the alcoholics, he would have hated me and his children." The interviewee is also responsible for paying for the monthly shopping to support the family and her husband pays for water and electricity, and the money left over from them both is deposited in the bank. She has five children, but only one, the youngest, lives with his parents. As he was getting married, they were transferring the property to him because "he will take care of us. They are building a house near us".

In the situations reported, it is clear that the elderly feel insecure and afraid of abandonment or violence. For Saidel and Campos", "guilt and anguish and even stress, aggression and sadness" are recurrent situations of violence in the lives of elderly family members. And the financial situation of families, as well as the transfer of land from parent to child, often does not occur in a fair, ethical and friendly manner. Sharing "the same roof as your father" and taking over "the role after [...] the physical strength of the parents is exhausted, [as] they concede the care of the establishment to their children", requires adaptation and resilience and can be frustrating, "creating conflicts that are difficult to resolve".

The study by Honnef et al. ${ }^{19}$, with 16 rural elderly persons from two municipal districts in Rio Grande do Sul, through interviews, showed that domestic violence is a complex social representation, with unequal relationships between men and women, affected by the "sexual division of labor, physical and psychological violence against women as a means of maintaining male dominance over them". Moreover, it is evident that many elderly persons feel abandoned and their financial resources are used by their children. 
The aging process transforms daily life, family ties and the future of the elderly. In new family configurations, subtle forms of indifference and disrespect may occur implicitly. This is the case of P1 and P2, who lived in a house and did not intend to leave. The youngest daughter proposed to "take responsibility for" her parents but put them out of their home. P1 revealed that now children generally,

\begin{abstract}
"Don't pay much attention to their parents, because we don't speak nicely, we are simple and all this generates violence. I treat it all as a joke, I don't care anymore, it goes in one ear and out the other. If I keep everything, I'll end up suffering much more".
\end{abstract}

The study by Guedes et al. ${ }^{20}$ showed that the relationship between gender, age and social conditions are determining factors in the experience of physical and psychological violence with the elderly, mainly practiced by family members. Thus, according to Minayo $^{12}$, one of the causes of the highest incidence of violence against the elderly is that $90 \%$ of them live in the family environment.

It is noteworthy that intrafamily violence involving the elderly is a recurrent, hidden and silent problem ${ }^{9,21,22}$. Therefore, further studies and an expansion of the sample of rural elderly persons are required to understand the issue systematically and propose alternatives to overcome the problem in a family, social and institutional context.

\section{REFERENCES}

1. Sá JLM, Doll J, Oliveira JFP, Herédia VBM. Multidimensionalidade do envelhecimento e interdisciplinaridade. In: Freitas EV, Py L. Tratado de Geriatria e gerontologia. 4. ed. Rio de Janeiro: Guanabara Koogan; 2016. p. 107-8.

2. Campos ACV, Ferreira EF, Vargas AMD. Determinantes do envelhecimento ativo segundo a qualidade de vida e gênero. Ciênc Saúde Colet. 2015;20:2221-37.

3. Mucida A. Atendimento psicanalítico do idoso. São Paulo: Zagodoni; 2014.

\section{CONCLUSION}

The results of the study show that the elderly conceived the process of aging in intrafamily living as positive and rewarding, with the possibility of playing with their grandchildren and participating in social groups, as a form of social insertion and sociability to overcome the loneliness of the absence of their children. They also mentioned that time, age, autonomy and independence are intrinsically connected to the historical and cultural context and may, on the one hand, reveal contradictory feelings, such as fear of loneliness, insecurity, fragility and dependence and, on the other, the projection of aging with more dignity and happiness. Regarding family experiences, they reported that the family is responsible for caring for, valuing and understanding the elderly and also indicated subtle and implicit practices of psychological, financial and abandonment, often feeling powerless and ashamed to take effective initiatives aimed at restoring cordial, ethical and harmonious family relationships.

The study also permitted an insight into the problem of domestic violence from the perspective of the elderly, who are often victims of aggression. One of the ways that the elderly find to open up, unburden themselves and find possible alternatives to the suffering they experience is in social and welcome groups.

Edited by: Ana Carolina Lima Cavaletti

4. Guimarães APS, Górios C, Rodrigues CL, Armond JE. Notification of intrafamily violence against elderly women in the city of São Paulo. Rev Bras Geriatr Gerontol. 2018;21(1):1-7.

5. Minayo MCS, Souza ER, Silva MMA, Assis SG. Institutionalizing the theme of violence within Brazil's national health system: progress and challenges. Ciênc Saúde Colet. 2018;23(6);2007-2016.

6. Silva DF, Ribeiro ML, Duval HC, Ferrante VLSB. As dificuldades de "passar o bastão": perspectivas da sucessão da propriedade entre produtores de comunidades rurais do município de Campos Gerais/ MG. Retr Assent. 2017;20(2):240-9. 
7. Brasil. Constituição (1988). Constituição da República Federativa do Brasil. Brasília, DF: Senado Federal: Centro Gráfico; 1988.

8. Lafin SHF. As relações familiares e o idoso: algumas reflexões. In: Bulla LC, Argimon IIL, Org. Convivendo com o familiar idoso. Porto Alegre: Edipucrs; 2009. p. 56-9.

9. Gerino E, Caldarera AM, Curti L, Brustia P, Rollè L. Intimate Partner Violence in the Golden Age: Systematic Review of Risk and Protective Factors. Front Psychol. 2018;9:1-14.

10. Rocha RC, Côrtes MCJW, Dias EC, Gontijo ED. Veiled and revealed violence against the elderly in Minas Gerais, Brazil: analysis of complaints and notifications. Saúde Debate. 2018;42(4):81-94.

11. Saidel MGB, Campos CJG. Family of older adults with mental disorder: perception of mental health professionals. Rev Bras Enferm. 2017;70(4):753-60.

12. Brasil. Secretaria de Direitos Humanos da Presidência da República. (SDH/PR) Manual de enfrentamento à violência contra a pessoa idosa: é possível prevenir; é necessário superar. Brasília,DF: Secretaria de Direitos Humanos da Presidência da República; 2013.

13. Beauvoir S. A velhice. Tradução Monteiro MHF. Rio de Janeiro: Nova Fronteira; 1990.

14. Instituto Brasileiro de Geografia e Estatística, Ministério do Planejamento, Orçamento e Gestão. Cidades [Internet]. Rio de Janeiro: IBGE; 2017 [acesso em 22 abr. 2019]. Disponível em: https:// cidades.ibge.gov.br/brasil/rs/santo-antonio-dopalma/ panorama
15. Bardin L. Análise de Conteúdo. 4. ed. Tradução Pinheiro LA. São Paulo: Edições 70; 2016.

16. Orlandi AAS, Brito TRP, Ottaviani AC, Rossetti ES, Zazzetta MS, Gratão ACM, et al. Profile of older adults caring for other older adults in contexts of high social vulnerability. Esc Anna Nery. 2017;21(1):1-8.

17. Menezes JN, Costa MPM, Iwata ACNS, Araujo PM, Oliveira LG, et al. A visão do idoso sobre o seu processo de envelhecimento. Rev Contexto Saúde. 2018;18(35):8-12.

18. Tavares VO, Teixeira KMD, Wajnman S, Loreto MDS. Interfaces entre a renda dos idosos aposentados rurais e o contexto familiar. Textos \& Contextos. 2011;10(1):94-108.

19. Honnef F, Costa MC, Arboit J, Silva EB, Marques KA. Representações sociais da violência doméstica em cenários rurais para mulheres e homens. Acta Paul Enferm. 2017;30(4):368-74.

20. Guedes DT, Alvarado BE, Phillips SEP, Curcio CL, Zunzunegui MV, Guerra RO. Socioeconomic status, social relations and domestic violence (DV) against elderly people in Canada, Albania, Colombia and Brazil. Arch Gerontol Geriatr. 2015;60(3):492-500.

21. Belisário MS, Dias FA, Pegorari MS, Paiva MM, Ferreira PCS, Corradini FA, et al. Cross-sectional study on the association between frailty and violence against community-dwelling elderly people in Brazil. Sao Paulo Med J. 2018;136(1):10-9.

22. Calvo MR, Mendoza CG, León TG, Llopis AA, Duran YD, Álvarez PR. Violencia intrafamiliar en el adulto mayor. Rev Arch Med Camagüey 2018;22(2):204-13. 